\title{
HUBUNGAN CUACA MIKRO DENGAN PREVALENSI PENYAKIT DEMAM BERDARAH DENGUE DI KABUPATEN BONE TAHUN 2013-2015 \\ H. Ashari Rasjid ${ }^{1}$ dan Nasrianti ${ }^{2}$ \\ 1,2Jurusan Kesehatan Lingkungan Poltekkes Kemenkes Makassar \\ rianti.anti@yahoo.co.id
}

\begin{abstract}
The incidence of dengue hemorrhagic fever can be caused by several factors such as environmental factors such as microclimate (rainfall, wind speed, humidity, temperature) that can support the increasing mosquitoes cause dengue hemorrhagic fever. The purpose of this study is to determine the relationship of micro-weather with the prevalence of dengue hemorrhagic fever in Bone District in 2013-2015. This type of research is an analytical study with a retrospective approach. The weather data was collected from the Central Bureau of Statistics of South Sulawesi Province and dengue hemorrhagic data was obtained from the Bone District Health Office in 2013-2015. Data were analyzed by correlation test. The results showed that air temperature $(p=0.484)$ showed no correlation with prevalence of dengue hemorrhagic fever, and humidity $(p=0,033)$, rainfall $(p=0,033)$ and wind velocity $(p=0,004)$ showed a significant correlation with dengue fever prevalence. From the result it can be concluded that there is no correlation between temperature with prevalence of dengue hemorrhagic fever and there is relation between humidity, rainfall and wind speed with prevalence of dengue hemorrhagic disease in bone district. Further research is suggested to use other weather that is suspected to have a relationship with the incidence of dengue hemorrhagic fever.

Keywords: Dengue hemorrhagic fever, temperature, humidity, rainfall, wind speed
\end{abstract}

\section{ABSTRAK}

Kejadian demam berdarah dengue dapat diakibatkan oleh beberapa faktor salah satunya yaitu faktor lingkungan seperti cuaca mikro (curah hujan, kecepatan angin, kelembaban, suhu) yang dapat mendukung bertambahnya pupulasi nyamuk terutama nyamuk penyebab penyakit demam berdarah dengue. Penelitian ini bertujuan untuk mengetahui hubungan cuaca mikro dengan prevalensi penyakit demam berdarah dengue di Kabupaten Bone tahun 2013-2015. Jenis penelitian ini merupakan studi analitik dengan pendekatan retrospektif. Data cuaca dikumpulkan dari Badan Pusat Statistik Provinsi Sulawesi Selatan dan data penyakit demam berdarah dengue dikumpulkan dari Dinas Kesehatan Kabupaten Bone tahun 2013-2015. Data dianalisis dengan uji korelasi. Hasil analisis menunjukkan bahwa suhu udara $(p=0,484)$ menunjukkan tidak ada hubungan dengan prevalensi demam berdarah dengue, dan kelembaban $(p=0,009)$, curah hujan $(p=0,033)$ dan kecepatan angin $(p=0,004)$ menunjukkan ada hubungan bermakna dengan prevalensi penyakit demam berdarah dengue. Dari hasil dapat disimpulkan bahwa tidak ada hubungan antara suhu dengan prevalensi penyakit demam berdarah dengue dan ada hubungan antara kelembaban, curah hujan dan kecepatan angin dengan prevalensi penyakit demam berdarah dengue di kabupaten Bone. Penelitian selanjutnya disarankan menggunakan indikator cuaca lainnya yang diduga mempunyai hubungan dengan kejadian demam berdarah dengue.

Keywoard: Demam berdarah dengue, suhu, kelembaban, curah hujan, kecepatan angin.

\section{PENDAHULUAN}

Penyakit Demam Berdarah Dengue atau DBD adalah penyakit menular yang disebabkan oleh virus dengue dan merupakan vector borne disease atau ditularkan melalui vektor, yaitu nyamuk Aedes. Penyakit DBD banyak dijumpai terutama di daerah tropis, telah muncul sebagai masalah kesehatan masyarakat internasional pada abad 21.

Banyak faktor yang mempengaruhi kejadian demam berdarah dengue antara lain faktor hospes (host), lingkungan (environment), dan faktor virus itu sendiri. Faktor hospes yaitu kerentanan (susceptibility), dan respons imun. Faktor lingkungan (environment) yaitu kondisi geografis (ketinggian dari permukaan laut, curah hujan, angin, kelembaban, musim), kondisi demografis (kepadatan, mobilitas, perilaku, adat istiadat, social ekonomi penduduk), jenis dan kepadatan nyamuk sebagai vektor penyakit. (Soegijanto, 2006)

$$
\text { Pengaruh cuaca misalnya berupa }
$$

pengaruh hujan, yang dapat menyebabkan kelembaban naik dan menambah jumlah tempat perindukan. Lebih jauh lagi, iklim dan cuaca dapat berpengaruh terhadap pola penyakit infeksi karena agen penyakit (virus, bakteri, atau parasit lainnya) dan vektor (serangga atau rodensia) bersifat sensitif terhadap suhu, kelembaban dan kondisi lingkungan ambien lainnya.

Curah hujan lebat dan banjir dapat memperburuk sistem sanitasi yang belum memadai di banyak wilayah kumuh di berbagai daerah dan kota, sehingga dapat membuat masyarakat rawan terkena penyakit-penyakit yang menular lewat air seperti diare dan kolera. Suhu tinggi dan kelembaban tinggi yang berkepanjangan juga dapat menyebabkan kelelahan akibat kepanasan terutama di kalangan masyarakat miskin kota dan para lansia. Dan suhu yang lebih tinggi juga memungkinkan nyamuk menyebar ke wilayahwilayah baru menimbulkan ancaman malaria dan demam berdarah dengue.

Selain itu, demam berdarah dengue merupakan penyakit musiman yang biasanya 
Jurnal Sulolipu : Media Komunikasi Sivitas Akademika dan Masyarakat

Vol. 17 No.II 2017

e-issn : 2622-6960, p-issn : 0854-624X

berhubungan dengan cuaca lebih hangat dan lebih lembab. Suhu ekstrim mengancam ketahanan hidup virus penyebab penyakit, tetapi perubahan pada suhu memungkinkan efek bervariasi. Suhu berhubungan dengan perubahan dinamika siklus hidup organisme vektor dan virus yang kemudian mampu meningkatkan transmisi potensial pada kejadian penyakit demam berdarah dengue. Jika suhu rendah dengan adanya sedikit peningkatan suhu akan meningkatkan perkembangan, inkubasi dan replikasi virus. Selain itu, suhu dapat memodifikasi pertumbuhan vektor pembawa penyakit dengan mengubah tingkat gigitan mereka. Sama seperti mempengaruhi dinamika populasi vektor dan mengubah tingkat kontak dengan manusia.

Di Indonesia kasus demam berdarah dilaporkan pertama kali di Jakarta dan Surabaya pada tahun 1968 dengan jumlah kasus sebanyak 58 orang dan 24 orang diantaranya meninggal. Pada tahun 2014, sampai pertengahan bulan Desember tercatat penderita demam berdarah dengue di 34 provinsi di Indonesia sebanyak 71.668 orang, dan 641 diantaranya meninggal dunia. Angka tersebut lebih rendah dibandingkan tahun sebelumnya, yakni tahun 2013 dengan jumlah penderita sebanyak 112.511 orang dan jumlah kasus meninggal 871 penderita. (Kemenkes RI, 2015)

Menurut data Dinas Kesehatan Sulawesi Selatan, pada tahun 2014 jumlah kasus demam berdarah dengue tercatat sebanyak 2.966 kasus, dan meninggal sebanyak 25 orang, Case Fatality Rate DBD (CFR) sebesar 0,84 \%. (Dinkes Provinsi Sulawesi Selatan, 2015)

Di Kabupaten Bone menurut laporan dari Seksi P2M tahun 2014, ditemukan 212 kasus (112 laki-laki dan 100 perempuan) di 28 Puskesmas. terjadi 2 kasus kematian (1 laki-laki dan 1 perempuan), dengan CFR 0,94\%. (Dinkes Kabupaten Bone, 2015).

\section{BAHAN DAN METODE}

1. Lokasi Penelitian

Penelitian ini dilakukan di Kabupaten Bone, Provinsi Sulawesi Selatan.

2. Variabel Penelitian

Variabel independen dalam penelitian ini yaitu suhu, kelembaban, curah hujan, dan kecepatan angin.

3. Sampel
Sampel dalam penelitian ini adalah kejadian demam berdarah dengue di Kabupaten Bone tahun 2013-2015. Dengan teknik pengambilan sampel yaitu metode Purposive Sampling.

4. Pengumpulan Data

Data dalam penelitian ini yaitu data sekunder dimana data penyakit diperoleh dari Dinas Kesehatan Kabupaten Bone dan data cuaca mikro Kabupaten Bone diperoleh dari Badan Pusat Statistik.

5. Analisis Data

Analisis statistik yang dilakukan adalah analisis univariant dan bivariate. Analisis univariat untuk memberi gambaran distribusi angka prevalensi DBD serta gambaran fluktuasi faktor iklim (suhu, kelembaban, curah hujan, dan kecepatan angin), analisis bivariate dengan menggunakan uji korelasi, dimana tingkat kemaknaan atau signifikan adalah $\alpha=0,05$ dimana dikatakan bermakna atau signifikan apabila $p<\alpha$. Kekuatan hubungan dua variabel secara kualitatif terbagi dalam 4 area,

$r=0,00-0,25$ tidak ada hubungan/hubungan lemah

$r=0,26-0,50$ hubungan sedang

$r=0,51-0,75$ hubungan kuat

$r=0,76-1,00$ hubungan sangat kuat/sempurna

\section{HASIL PENELITIAN}

Tabel 1

Hasil Analisis Korelasi Suhu Dengan

Kejadian Demam Berdarah Dengue di Kabupaten Bone Tahun 2013-2015

\begin{tabular}{ccccc}
\hline $\begin{array}{c}\text { Varia } \\
\text { bel }\end{array}$ & $\begin{array}{c}\text { Koef.Korela } \\
\mathbf{s i}\end{array}$ & $\begin{array}{c}\text { Signifikan } \\
\mathbf{s i}(\mathbf{p})\end{array}$ & $\begin{array}{c}\text { Jumla } \\
\mathbf{h}(\mathbf{n})\end{array}$ & $\begin{array}{c}\text { Keterang } \\
\text { an }\end{array}$ \\
\hline Suhu & 0.224 & 0.484 & 36 & $\begin{array}{c}\text { Tidak ada } \\
\text { hubungan }\end{array}$ \\
\hline
\end{tabular}

Berdasarkan tabel 1, hasil uji statistik antara kejadian demam berdarah dengue dengan suhu diperoleh nilai $r=0.224$ dengan nilai signifikan $p=0,484>\alpha=005$. Dengan nilai $p$ yang lebih besar dari a $(0,05)$, maka dapat disimpukan bahwa tidak ada hubungan bermakna antara kejadian demam berdarah dengue dengan suhu. 
Jurnal Sulolipu : Media Komunikasi Sivitas Akademika dan Masyarakat

Vol. 17 No.II 2017

e-issn : 2622-6960, p-issn : 0854-624X

\section{Tabel 2 \\ Hasil Analisis Korelasi Kelembaban \\ Dengan Kejadian Demam Bedarah Dengue di Kabupaten Bone Tahun 2013-2015}

\begin{tabular}{ccccc}
\hline Variabel & $\begin{array}{c}\text { Koef.Korel } \\
\text { asi }(\mathbf{r})\end{array}$ & $\begin{array}{c}\text { Signifika } \\
\mathbf{n s i}(\mathbf{p})\end{array}$ & $\begin{array}{c}\text { Jumla } \\
\mathbf{h}(\mathbf{n})\end{array}$ & $\begin{array}{c}\text { Keteran } \\
\text { gan }\end{array}$ \\
\hline $\begin{array}{c}\text { Kelemba } \\
\text { ban }\end{array}$ & 0.599 & 0.009 & 36 & $\begin{array}{c}\text { Ada } \\
\text { hubunga } \\
\mathbf{n}\end{array}$ \\
\hline Berdasarkan & tabel & 2, & pada & tabel
\end{tabular}

kelembaban dengan kejadian demam berdarah dengue didapatkan nilai $r$ sebesar 0.599 dengan nilai signifikaan atau $p=0.009$. Ini berarti bahwa kelembaban mempunyai kekuatan hubungan yang kuat dan mempunyai arah korelasi positif yaitu kejadian demam berdarah dengue akan meningkat bila kelembaban meningkat. Nilai $p$ yang lebih kecil dari a (0.05) dapat disimpulkan bahwa ada hubungan bermakna antara kejadian demam berdarah dengue dengan kelembaban selama tahun 2013-2015.

Tabel 3

Hasil Analisis Korelasi Curah Hujan Dengan Kejadian Demam Berdarah Dengue di Kabupaten Bone Tahun 2013-2015

\begin{tabular}{lcccc}
\hline $\begin{array}{c}\text { Variab } \\
\text { el }\end{array}$ & $\begin{array}{c}\text { Koef.Korel } \\
\text { asi }(\mathbf{r})\end{array}$ & $\begin{array}{c}\text { Signifik } \\
\text { ansi }(\mathbf{p})\end{array}$ & $\begin{array}{c}\text { Juml } \\
\text { ah }(\mathbf{n})\end{array}$ & $\begin{array}{c}\text { Keteran } \\
\text { gan }\end{array}$ \\
\hline $\begin{array}{l}\text { Curah } \\
\text { hujan }\end{array}$ & 0.62 & 0.033 & 36 & $\begin{array}{c}\text { Ada } \\
\text { hubunga } \\
n\end{array}$ \\
\hline
\end{tabular}

Berdasarkan tabel 3, hasil pengujian pada variabel curah hujan menunjukkan nilai $r=0.617$ yang berarti korelasi mempunyai hubungan kuat dan berpola positif yang artinya jumlah kejadian demam berdarah dengue akan meningkat bila curah hujan meningkat. Nilai signifikan atau $p=0,033<\alpha=0,05$ sehingga dapat disimpulkan bahwa ada hubungan bermakna antara curah hujan dengan kejadian demam berdarah dengue selama periode tahun 2013-2015.

Tabel 4

Hasil Analisis Korelasi Kecepatan Angin Dengan Kejadian Demam Berdarah Dengue di Kabupaten Bone Tahun 2013-2015

\begin{tabular}{ccccc}
\hline $\begin{array}{c}\text { Variabe } \\
\text { I }\end{array}$ & $\begin{array}{c}\text { Koef.Korela } \\
\mathbf{s i}(\mathbf{r})\end{array}$ & $\begin{array}{c}\text { Signifika } \\
\mathbf{n s i}(\mathbf{p})\end{array}$ & $\begin{array}{c}\text { Jumla } \\
\mathbf{h}(\mathbf{n})\end{array}$ & $\begin{array}{c}\text { Keterang } \\
\text { an }\end{array}$ \\
$\begin{array}{c}\text { Kecepa } \\
\text { tan }\end{array}$ & 0.767 & 0.004 & 36 & $\begin{array}{c}\text { Ada } \\
\text { hubunga } \\
\text { Angin }\end{array}$ \\
\hline
\end{tabular}

Berdasarkan tabel 4, hasil uji statistik antara kejadian demam berdarah dengue dengan kecepatan angin menunjukkan nilai $r$ sebesar 0,767 dengan nilai signifikan atau $p=0,004$. Ini berarti bahwa kecepatan angin mempunyai kekuatan sangat kuat dan dari nilai $p$ yang lebih besar dari nilai a (005). Maka dapat disimpulkan bahwa ada hubungan yang bermakna antara kecepatan angin dengan kejadian demam berdarah dengue pada periode tahun 2013-2015.

\section{PEMBAHASAN}

1. Hubungan Suhu Dengan Prevalensi Penyakit Demam Berdarah Dengue di Kabupaten Bone Tahun 2013-2015

Hasil penelitian menunjukkan bahwa suhu udara rata-rata di Kabupaten Bone selama periode waktu $2013-2015$ adalah yaitu $26,4^{\circ} \mathrm{C}$. Dengan suhu minimal yaitu $24^{\circ} \mathrm{C}$, dan suhu maksimum yaitu $28,9^{\circ} \mathrm{C}$.

Berdasarkan hasil pengujian statistik dengan SPSS diperoleh koefisien korelasi variabel suhu dengan kejadian demam berdarah sebesar 0,224 dengan nilai $p=0,484$ dimana nilai $p>\alpha$, sehingga dapat dikatakan bahwa tidak terdapat hubungan bermakna atau signifikan antara suhu dengan kejadian demam berdarah di Kabupaten Bone tahun 2013-2015.

Ini menunjukkan bahwa perubahan pada suhu selama periode tahun 2013-2015 menunjukkan tidak ada hubungan yang bermakna terhadap kejadian demam berdarah dengue dengan tingkat hubungan sedang dan arah hubungan negative yaitu jika suhu udara mulai naik, maka ada kecenderungan kejadian demam berdarah dengue menurun dan juga sebaliknya pada suhu udara mulai turun, kejadian demam berdarah dengue cenderung meningkat.

Peningkatan angka kejadian demam berdarah dengue dapat dipengaruhi oleh banyak hal termasuk suhu, meskipun suhu di Kabupaten Bone merupakan suhu optimal dan dapat menyebabkan jumlah vektor meningkat, namum hasil menunjukkan tidak ada hubungan bermakna antara suhu dengan kejadian demam berdarah dengue di Kabupaten Bone. Hal ini mungkin terjadi karena faktor-faktor lain yang mendukung peningkatan pupulasi nyamuk penyebab penyakit demam berdarah dengue, sehingga angka penyakit demam berdarah dengue tetap tinggi meskipun suhu merupakan suhu optimal. 
Jurnal Sulolipu : Media Komunikasi Sivitas Akademika dan Masyarakat

Vol. 17 No.II 2017

e-issn : 2622-6960, p-issn : 0854-624X

Naiknya suhu udara akibat perubahan cuaca dapat menyebabkan masa inkubasi nyamuk semakin pendek. Dampak, nyamuk akan berkembangbiak lebih cepat. Meningkatnya populasi vektor nyamuk akan meningkatkan peluang agen-agen penyakit dengan vektor nyamuk.

Nyamuk dapat bertahan hidup pada suhu rendah $\left(10^{\circ} \mathrm{C}\right)$, tetapi metabolismenya menurun atau bahkan terhenti bila suhunya turun sampai dibawah suhu kritis $4,5^{\circ} \mathrm{C}$. Pada suhu yang lebih tinggi dari $35^{\circ} \mathrm{C}$ juga mengalami perubahan dalam arti lebih lambatnya prosesproses fisiologis, rata-rata suhu optimum untuk pertumbuhan nyamuk adalah $25-35^{\circ} \mathrm{C}$. Suhu udara mempengaruhi perkembangan virus dalam tubuh nyamuk, tingkat menggigit, istirahat dan perilaku kawin, penyebaran dan durasi siklus gonophonik. (Widya, 2006 dalam Wirayoga, 2013).

Hal ini sejalan dengan penelitian Rohaedi (2008) di Jakarta Barat tahun 2007 yang mengatakan tidak terdapat hubungan yang bermakna antara suhu dengan kejadian DBD di Jakarta Barat.

Begitupula dengan hasil penelitian Sungono (2004) di Jakarta Utara (2004) di Jakarta Utara tahun 1999-2003 yang mengatakan bahwa tidak ada hubungan bermakna antara suhu dengan angka kejadian demam berdarah dengue.

\section{Hubungan Kelembaban dengan Prevalensi Penyakit Demam Berdarah Dengue di Kabupaten Bone Tahun 2013-2015}

Hasil penelitian rata-rata kelembaban di Kabupaten Bone tahun 2013-2015 adalah 84\%. Dengan kelembaban terendah $71 \%$ pada tahun 2013 , dan kelembaban tertinggi yaitu $89 \%$ pada tahun 2013.

Berdasarkan hasil pengujian statistik dengan SPSS diperoleh koefisien korelasi kelembaban sebesar 0.599 dengan signifikansi atau $p=0.009$ dimana nilai $p<\alpha$ dengan demikian dapat disimpulkan bahwa terdapat hubungan bermana atau signifikan antara kelembaban dengan kejadian demam berdarah tahun 20132015.

Hal ini menunjukkan bahwa perubahan kelembaban selama periode tahun 2013-2015 memberikan pengaruh yang bermakna dengan tingkat hubungan kuat. Kelembaban rata-rata selama periode 2013-2015 di Kabupaten Bone adalah berkisar antara $80-90 \%$. Kelembaban tersebut dalam batas optimal vektor untuk berkembang biak, sehingga bermaknanya hubungan antara kelembaban dan prevalensi DBD di Kabupaten Bone dapat terjadi.

Sistem pernafasan nyamuk menggunakan pipa udara (trackea) dengan lubang-lubang pada dinding tubuh nyamuk (spiracle). Adanya spiracle yang terbuka lebar tanpa ada mekanisme pengaturannya. Saat kelembaban rendah menyebabkan penguapan air dari dalam tubuh sehingga menyebabkan keringnya cairan dalam tubuh. Salah satu musuh nyamuk adalah penguapan. Kelembaban berpengaruh terhadap umur nyamuk, jarak terbang, kecepatan berkembangbiak, kebiasaan menggigit, istirahat, dan lain-lain.

Kelembaban dapat mempengaruhi transmisi nyamuk. Kemampuan nyamuk dalam bertahan hidup mengalami penurunan pada kondisi kering. Demam berdarah dengue menunjukkan pola yang berkaitan dengan iklim terutama kelembaban karena mempengaruhi penyebaran vector nyamuk dan kemungkinan menularkan virus dari satu manusia ke manusia lain. Pada kelembaban kurang dari 60\% umur nyamuk akan menjadi pendek, tidak bisa menjadi vektor karena tidak cukup waktu untuk perpindahan virus dari lambung ke kelenjar ludah. Kelembaban rata-rata di Kabupaten Bone $84 \%$ yang merupakan kelebaban yang sesuai untuk proses perkembangan nyamuk, dimana kelembaban udara berkisar 71,5\%-89,5\% merupakan kelembaban yang optimal untuk proses embrioisasi dan ketahanan hidup embrio nyamuk.

Penelitian ini sejalan dengan penelitian Wirayoga (2013) yang menyatakan bahwa kerjadian demam berdarah dengue mempunyai hubungan yang kuat atau signifikan dengan kelembaban di Kota Semarang tahun 20062011.

3. Hubungan Curah Hujan Dengan Prevalensi Penyakit Demam Berdarah Dengue di Kabupaten Bone Tahun 2013-2015.

Rata-rata curah hujan di Kabupaten Bone tahun 2013-2015 Rata-rata curah hujan sepanjang tahun 2013-2015 yaitu $222 \mathrm{~mm}$. Curah hujan tertinggi tahun 2013 terjadi di bulan januari yaitu sebesar $1308 \mathrm{~mm}$, kemudian mengalami penurunan hingga mencapai curah hujan terendah pada bulan September dan kembali naik pada bulan desember yaitu sebesar 813 mm. Pada tahun 2014, curah hujan tertinggi terjadi pada bulan mei hingga bulan juni yaitu 
sebesar 594-638 $\mathrm{mm}$, dan terus mengalami penurunan hingga $0 \mathrm{~mm}$ pada bulan September. Kemudian pada tahun 2015 curah hujan tertinggi terjadi pada bulan Juni yaitu sebesar $384 \mathrm{~mm}$, juga terus mengalami penurunan hingga $0 \mathrm{~mm}$ pada September dan Oktober tahun 2015.

Berdasarkan hasil penelitian statistik dengan SPSS diperoleh nilai koefisien korelasi variabel curah hujan sebesar 0,617 dengan signifikansi 0,033 artinya $p<\alpha=0,05$. Dengan demikian dapat disimpulkan bahwa terdapat hubungan positif yang sigifikan antara curah hujan dengan prevalensi penyakit demam berdarah dengue.

Hal ini membuktikan bahwa perubahan curah hujan selama tahun 2013-2015 memberikan pengaruh yang bermakna bagi kejadian demam berdarah dengue. Hujan dapat mempengaruhi kehidupan nyamuk dengan 2 cara yaitu menyebabkan naiknya kelembaban nisbi udara dan menambah tempat perindukan. Setiap 1 $\mathrm{mm}$ curah hujan menambah kepadatan nyamuk 1 ekor, akan tetapi apabila curah hujan dalam seminggu sebesar $140 \mathrm{~mm}$, maka larva akan hanyut dan mati. (Thomas, 2000 dalam wirayoga 2013).

Curah hujan yang mendukung bertambahnya populasi nyamuk yaitu apabila curah hujan 300 $\mathrm{mm} /$ bulan. Curah hujan merupakan faktor penentu tersedianya tempat perindukan bagi nyamuk. Hujan dengan intensitas yang sukup akan menimbulkan genangan air di tempattempat penampungan air sekitar rumah maupun cekungan-cekungan yang merupakan tempat telur nyamuk menetas hingga menjadi pupa sebelum menjadi nyamuk dewasa. Sebaliknya jika curah hujan yang besar akan meyebabkan genangan air akan melimpah sehingga larva atau pupa nyamuk tersebar ke tempat-tempat lain yang tidak sesuai untuk pertumbuhan nyamuk.

Hasil penelitian ini sejalan dengan penelitian Wirayoga (2013) bahwa terdapat hubungan signifikan antara curah hujan dengan kejadian DBD curah hujan di Kota Semarang tahun 20062011.

4. Hubungan Kecepatan Angin Dengan Prevalensi Penyakit Demam Berdarah Dengue Tahun 2013-2015

Rata-rata kecepatan angin di Kabupaten Bone tahun 2013-2015 yaitu $3 \mathrm{~km} / \mathrm{jam}$. Kecepatan angin tertinggi di Kabupaten Bone sepanjang tahun 2013-2015 terjadi pada bulan September tahun 2015 yaitu $10 \mathrm{~km} / \mathrm{jam}$, dan kecepatan angin terendah terjadi pada bulan april-juli 2013 yaitu $1 \mathrm{~km} / \mathrm{jam}$. Dari data dapat dilihat distribusi kecepatan angin di Kabupaten Bone relatif sama di tiap tahunnya.

Berdasarkan hasil pengujian statistik dengan SPSS diperoleh koefisien korelasi variabel kecepatan angin sebesar 0,767 dengan signifikansi 0,004 yang artinya $p<\alpha=0,05$. Dapat disimpulkan bahwa terhadap hubungan positif antara kecepatan angin dengan kejadian demam berdarah di Kabupaten Bone tahun 2013-2015.

Hal ini membuktikan bahwa kecepatan angin memiliki pengaruh terhadap peningkatan kejadian demam berdarah dengue di Kabupaten Bone selama tahun 2013-2015. Kecepatan angin akan mempengaruhi daya jangkau terbang nyamuk. Semakin luas daya jangkau nyamuk, maka semakin banyak kesempatan untuk kontak dengan manusia sehingga umur dan masa untuk kontak dengan manusia sehingga umur dan masa reproduksi nyamuk akan semakin panjang. Semakin tinggi kecepatan angin maka semakin sulit bagi vektor untuk terbang. Oleh karena itu, nyamuk sulit untuk berpindah-pindah tempat dengan jarak yang jauh sehingga kemungkinan nyamuk untuk menularkan kecil.

Angin dapat berpengaruh pada penerbangan dan penyebaran nyamuk. Bila kecepatan angin 11-14 m/detik atau 25-31 mil/jam, akan menghambat penerbangan nyamuk. Kecepatan angin pada saat terbang nyamuk ke dalam atau luar rumah, adalah salah satu faktor yang ikut menentukan jumlah kontak antara manusia dan nyamuk. Jarak terbang nyamuk dapat diperpendek atau di perpanjang tergantung arah angin. (Widya, 2006 dalam wirayoga, 2013). Kecepatan angin pada saat matahari terbit dan tenggelam yang merupakan saat terbang nyamuk kedalam atau luar rumah, adalah salah satu faktor yang ikut menentukan jumlah kontak antara manusia dan nyamuk.

Penelitian ini sejalan dengan penelitian Junghans Sitorus (2003) yang menyimpulkan bahwa terdapat hubungan yang bermakna antara faktor iklim kecepatan angin dan kejadian DBD di Kotamadya Jakarta Timur tahun 19982002. 


\section{PENUTUP}

\section{Kesimpulan}

a. Tidak ada hubungan yang bermakna antara suhu udara dengan prevalensi penyakit demam berdarah dengue di Kabupaten Bone.

b. Ada hubungan yang bermakna antara kelembaban udara dengan prevalensi penyakit demam berdarah dengue di Kabupaten Bone

c. Ada hubungan yang bermakna antara curah hujan dengan prevalensi penyakit demam berdarah dengue di Kabupaten Bone

d. Ada hubungan yang bermakna antara kecepatan angin dengan prevalensi penyakit demam berdarah dengue di Kabupaten Bone

\section{Saran}

a. Saran untuk masyarakat agar ikut berpartisipasi dalam upaya pencegahan dengan cara tidak membisakan diri dengan lingkungan yang lembab dan tidak membiarkan genangan air di tempat yang lembab karena dapat mendukung pertumbuhan nyamuk

b. Penelitian selanjutnya disarankan menggunakan desain, lokasi, dan variabel yang berbeda, dan rentan waktu yang lebioh panjang.. Tidak hanya menggunakan variabel suhu udara, curah hujan, kelembaban, dan kecepatan angin saja akan tetapi dengan variabel iklim lainnya yang diduga mempunyai hubungan dengan DBD.

\section{DAFTAR PUSTAKA}

Dinas Kesehatan Provinsi Sulawesi Selatan. 2015. Profil Kesehatan Sulawesi Selatan. http://www.depkes.go.id/resources/download/ profil/PROFIL_KES_PROVINSI_2014/27_Sulawesi_Selatan_2014.pdf. Makassar: Dinas Kesehatan Republik Indonesia. Diakses tanggal 11 Januari 2017.

Dinas Kesehatan Kabupaten Bone. 2015. Profil Kesehatan Kabupaten Bone, http://www.depkes.go.id/resources/download/profil/PROF

IL_KAB_KOTA_2014/7311_Sulsel_Kab_Bone_2014.pdf, Bone: Dinas Kesehatan Kabupaten Bone. Diakses Pada Tanggal 11 Januari 2017.

Junghans Sitorus. 2003. Hubungan Iklim dengan Kasus Penyakit Demam Berdarah Dengue (DBD) di Kotamadya Jakarta Timur Tahun 1998-2002, http://lib.universitasindonesia.ac.id/19477/1/ 6452403073.pdf. Jakarta: Universitas Indonesia. Di akses pada tanggal 20 Mei 2017.

Kemenkes 2015.2 Profil Kesehatan Indonesia, http://www.depkes.go.id/resources/download/pusdatin/profil-kesehatan-indonesia/profilkesehatan-indonesia-2014.pdf. Jakarta: Kementerian Kesehatan Republik Indonesia. Diakses tanggal 11 Januari 2017.

Roehadi D. 2008. Faktor-faktor yang mempengaruhi kejadian Demam Berdarah Dengue di Wilayah Kotamadya Jakarta Barat Tahun 2007. http://lib.Ul.ac.id/1148717/1331/6450507074.pdf. Jakarta: Universitas Indonesia. Diakses Pada Tanggal 10 januari 2017.

Soegijanto, S. 2006. Demam Berdarah Dengue. Surabaya: Pusat Penerbit dan Percetakan Unair (AUP).

Sungono V. 2004. Hubungan Iklim dengan ABJ dan Kejadian Demam Berdarah Dengue di Kotamadya Jakarta Utara Tahun 1999-2003. http://lib.Ul.ac.id/19377/1331/645054633466407074.pdf. Jakarta: Universitas Indonesia. Diakses Pada Tanggal 10 juni 2017. 
Jurnal Sulolipu : Media Komunikasi Sivitas Akademika dan Masyarakat Vol. 17 No.II 2017

e-issn : 2622-6960, p-issn : 0854-624X

Wirayoga, M.A. 2013. Hubungan Kejadian Demam Berdarah Dengue Dengan Iklim di Kota Semarang Tahun 2006-2011, http://lib.unnes.ac.id/19377/1/6450407074.pdf. Surabaya: Universitas Negeri Semarang. Diakses Pada Tanggal 10 januari 2017. 